\title{
Dondurularak ve Püskürterek Kurutulmuş Süt Tozlarının Bazı Mikrobiyolojik ve Fizikokimyasal Özelliklerinin Karşılaştırılması
}

\author{
Sabire YERLİKAYA*, Hülya ŞEN ARSLAN \\ Karamanoğlu Mehmetbey University Food Engineering Department, Karaman \\ (ORCID: 0000-0001-9842-5848) (ORCID: 0000-0002-1662-2942)
}

\begin{abstract}
Öz
$\mathrm{Bu}$ çalışmada dondurularak ve püskürterek kurutulan süt tozlarının bazı mikrobiyolojik ve fizikokimyasal özellikleri depolama süresi boyunca araştırılmıştır. İlk olarak sütler iki gruba ayrılmıştır. İlk grup süt dondurarak kurutucu ile ikinci grup ise püskürtmeli kurutucu ile kurutulmuştur. Oda sıcaklığında, depolamanın 2., 4.ve 6.günlerinde toplam aerofilik mezofilik bakteri, maya-küf, toplam koliform ve fekal koliform, nem, hunter renk analizi, su aktivitesi, pH analizleri yapılmıştır. Su absorplama indeksi, suda çözünme indeksi analizleri depolamanın yalnızca 2.gününde; protein ve mikroskopik analizler depolamanın yalnızca 6.gününde gerçekleştirilmiştir. Dondurarak kurutma ile üretilen örneklerin nem, su aktivitesi, mikrobiyolojik analiz, $L$ değeri ve su absorplama indeksi sonuçları bütün depolama günleri için püskürterek kurutma ile üretilen örneklerin değerlerinden daha düşük olarak bulunmuştur. Dondurarak kurutulan örneklerin mikrobiyolojik kalitesinin daha iyi olduğu saptanmıştır. Elde edilen sonuçlar düşünüldüğünde dondurarak kurutma ile üretilen süt tozlarının oda sıcaklığında daha uzun raf ömrüne sahip olabileceği düşünülmüştür.
\end{abstract}

Anahtar kelimeler: Süt Tozu, Püskürtmeli Kurutma, Dondurarak Kurutma, Mikrobiyoloji.

\section{Comparison Some Microbiological and Physicochemical Properties of Freeze Dryed and Spray Dryed Milk Powder}

\begin{abstract}
In this research, some microbiological and physicochemical properties of milk powder produced by freeze dryer and spray dryer were determined during the storage period. Firstly, milks were divided into two groups. First group was dryed with freeze dryer. Second group was dryed with spray dryer. Total aerobic mesophilic bacteria, mouldyeast, total coliform and fecal coliform, moisture, hunter colour determination, water activity, $\mathrm{pH}$ analyses were performed in 2., 4. and 6. days of storage at room temperatures. Water absorption index, water solubility index analysis were performed only on the 2nd day of storage; protein and microscopic analyzes were performed only on the 6th day of storage. Moisture, water activity, microbiological analysis, $L$ value and water absorption index values of freeze dryed milk powders were found lower than spray dryed samples in all days of storage. Microbiological quality of freeze dryed milk powder is better. It was thaught that the milk powder produced by freeze drying may have a longer shelf life at room temperature.
\end{abstract}

Keywords: Milk Powder, Spray Dryer, Freeze Dryer, Microbiology.

\section{Giriş}

Drying of foods is a unit operation that dates back to ancient times and continues to evolve under everchanging technological advancements, resulting in reduced energy usage and improved quality of the final product [1]. Drying enables the design of new product formulations and at the same time, extends the shelf life of foods [2]. It is not possible to claim that a single drying method will be sufficient to meet the desired quality and drying economics of all food products; therefore, different drying methods with properly selected drying parameters should be applied to different food stuffs. Drying is a process in

*Sorumlu yazar:sabirebattal@ kmu.edu.tr

Geliş Tarihi: 10.01.2019, Kabul Tarihi: 09.05.2019 
which microorganisms and chemical reactions that cause deterioration are stopped or slowed down [3]. Drying technology consists of microwave drying, freeze drying, infrared drying and extrusion technology in addition to kiln dryers, tunnel dryers, spray dryers, drill dryers, roller dryers [3]. It should be considered during all applications that the main purpose of the drying process is not to dry faster but to obtain a better quality product [4].

Freeze drying generally consists of two steps, namely product freezing and direct sublimation drying of the product under reduced pressure [5]. Freeze drying is better drying method because of the first appearance, taste, color, flavor, structure preservation of the raw material. The product also has good rehydration properties as it retains its initial shapeand size [6]. Freeze drying is shown as an attractive method to extend the shelf life of foods $[5,7]$.

Spray drying is the most effective drying method known for the drying of pumpable liquids with high water content. In spray drying, the fluid is sprayed into the drying medium in small droplets. These droplets move in the environment of hot gas (usually air is used), and in this process, they dry in the form of small particles [8]. The spray drying process is as old as the history of dairy industry [8, 9]. In milk powder industry, spray dryer technology is the most common technique.

In this research, some microbiological and physicochemical properties of milk powder produced with freeze dryer and spray dryer were determined during the storage period. Spay dryer is used in the food industry for the production of milk powder. Some microbiological and physicochemical properties of milk powder produced by freeze dryer were wanted to be compared with spay dryer. In terms of milk powder production, it has been investigated whether freeze dryer is an alternative to spray dryer for industry. The advantages and disadvantages of these two techniques have been investigated.

\section{Material and Methods}

\subsection{Production of freeze dryed and spray dryed milk powder}

Milk (UHT) used in this research was purchased from a local markets in Karaman, Turkey. The composition of the milk as labelled in the packaging is given in Table 1. The milk was transported to the Food Engineering Department in Engineering Faculty of Karamanoğlu Mehmetbey University under hygienic conditions and processed immediately upon arrival. Milks were divided into two groups. First group was freezed at $\left(-18^{\circ} \mathrm{C}\right)$ for 12 hours. Then it was dryed with freeze dryer (at $-101^{\circ} \mathrm{C}$, for 6 day) (Scanvac-coolsafe). Second group was dryed with spray dryer (aspirator 80\%, pumb 25\%, inlet temperature $170^{\circ} \mathrm{C}$, outlet temperature $80^{\circ} \mathrm{C}$ ) (Büchi Mini Spray Dryer B-290). The powders were stored at room temperatures for 6 days. Total aerobic mesophilic bacteria, mould-yeast, total coliform and fecal coliform, moisture, hunter colour determination, water activity, $\mathrm{pH}$ analyses were performed in 2., 4 . and 6. days of storage. The storage period is not maintained for a long time as the microbial load is estimated to increase due to the increase in moisture content of the samples at room temperature. Since the aim is the comparison of two techniques, 6-day storage was thought sufficient to get enough results. Water absorption index, water solubility index analysis were performed only on the 2nd day of storage; protein and microscopic analyzes were performed only on the 6th day of storage. All analyses were conducted in two repetitions with two replicates.

Table 1. The composition of the UHT milk

\begin{tabular}{cc}
\hline Nutrients & UHT milk \\
\hline Energy kcal/kj & $31,7 / 132,5$ \\
Protein $(\mathrm{g})$ & 3,1 \\
Fat $(\mathrm{g})$ & 0,15 \\
Carbohydrate $(\mathrm{g})$ & 4,5 \\
\hline
\end{tabular}

\subsection{Total aerobic mesophilic bacteria}

Plate Count Agar (PCA) (Merck, Germany) was used as the medium. From the prepared dilutions, 0,1 $\mathrm{mL}$ was transferred to the petri dishes and seeded by spreading plate method. The petri dishes were 
incubated at $30^{\circ} \mathrm{C}$ for $24-48$ hours. Developed colonies were counted at the end of incubation and the results were given as cob / $\mathrm{ml}[10]$.

\subsection{Mould-yeast}

Patato Dextrose Agar (PDA) (Merck, Germany) with sterilized $10 \%$ tartaric acid was used for yeastmold counting. $0.1 \mathrm{~mL}$ of prepared dilutions were transferred to petri dishes containing PDA and incubated at $28^{\circ} \mathrm{C}$ for $4-5$ days. Developed all colonies at the end of incubation were considered as yeastmold [11].

\subsection{Total coliform and fecal coliform}

Total coliform and fecal coliform analysis were performed using the most probable counting (EMS-3 tube) method. In the EMS method, $1 \mathrm{~mL}$ of the previously prepared sample dilutions was added to 3 tubes containing Laurly Sulphate Tryptose Broth (LSTB) (Merck, Germany) containing durham tube and the tubes were incubated at $37^{\circ} \mathrm{C}$ for $24-48$ hours. At the end of the incubation, gas positive tubes were determined and the number of coliform bacteria was calculated by using EMS table. This value was multiplied by the dilution factor of the first dilution to calculate the number of possible coliform bacteria in 1 gram sample. To make a fecal coliform count, EC (E.coli) broth has durham tubes was seeded from positive LSTB tubes. The tubes were then incubated at $45 \pm 0.5^{\circ} \mathrm{C}$ for $24-48$ hours. At the end of incubation, the gases positive tubes were determined and the number of possible fecal bacteria in $1 \mathrm{~mL}$ of the first dilution was determined using the EMS table. This value was multiplied by the first dilution factor and the possible fecal coliform bacteria number in 1 gram of food was calculated [12].

\subsection{Moisture}

Standard methods of the AOAC were used to determine moisture (hot air oven). Moisture (\%) was determined by drying a $5 \mathrm{~g}$ sample at $105 \pm 2{ }^{\circ} \mathrm{C}$ to constant weight [13].

\subsection{Hunter colour determination}

The colours of powder samples were measured using a Hunter-Lab spectrocolorimeter (Labscan XE, Hunter Associates Laboratory Inc., Reston, VA, USA). Measurements were made from three differentpoints in samples. The colorimeter was calibrated using the standard white plate. The colour parameters such as $L^{*}$ (lightness), $a^{*}$ (redness/greenness) and $b^{*}$ (yellowness/blueness) were measured with the illuminant $\mathrm{C}$ and a 10 standard observer [14].

\subsection{Protein}

Crude protein (\%) was analysed according to the Kjeldahl method. Factor 6.25 was used for conversion of nitrogen to crude protein [15].

\subsection{Water absorption and water dissolution index}

After $0.5 \mathrm{~g}$ of samples were placed in the centrifuge tube, $10 \mathrm{ml}$ of pure water was added at $25^{\circ} \mathrm{C}$. The prepared mixture was allowed to stand at room temperature for $30 \mathrm{~min}$ with stirring at $5 \mathrm{~min}$. Samples were centrifuged at 7000xg for 15 minutes (5804R, Eppendorf centrifuge, Hamburg, Germany). The liquid portion on the centrifuge tube was poured into pre-tared aluminum containers and dried in an oven at $105^{\circ} \mathrm{C}$ until constant weighing. The weight of the remaining gel portion in the centrifuge tube was measured by measuring the precision scale [16]. Water absorption index (1) and water dissolution index (2) were calculated as follows.

Water absorption index $\left(\frac{g}{g}\right)=\frac{\text { gelweight }(g)}{\text { Weightofsample }(\text { ondrybasis })(g)}$ 
Watersolubilityindex $(\%)=\frac{\text { Weightofdissolvedsubstanceinwaterphase }(g)}{\text { Weightofsample }(\text { ondrybasis })(g)} \times 100$

\subsection{Water activity}

The water activity values of each sample were determined according to the water activity determination method [17]. Water activity (aw) values are calculated according to the following Formula (3): $\mathrm{a}_{\mathrm{w}}=\mathrm{P} / \mathrm{P}_{0}=\mathrm{ERH} / 100(3)$

\subsection{0. pH}

For $\mathrm{pH}$ determination, $10 \mathrm{~g}$ of each sample was homogenized in $100 \mathrm{~mL}$ of distilled water for $1 \mathrm{~min}$ using a blender (Waring Commercial Blendor ${ }^{\circledR}$, USA). Then, $\mathrm{pH}$ value was measured using a $\mathrm{pH}$ meter (pH 315i/SET WTW, Germany) [18].

\subsection{Microscopy}

Images were taken by a microscop (LEICA S8AP0) with 160x in just 6.day of storage.

\subsection{Statistical analysis}

The results obtained from the analyzes mentioned in the method section were analyzed statistically using SPSS 22 (IBM Corp., Armonk, New York, USA) program. The samples were tested in 2 replications, 2 in parallel. The sample mean was compared within dependent $\mathrm{T}$ test. According to the Levene test of variances, $\mathrm{p}<0.05$; shows that the difference between the two groups is important.

\section{Result and Discussion}

\subsection{Production of freeze dryed and spray dryed milk powder}

Freeze dryed milk powder was produced in 144 hours with $\% 89,15$ performance $(115 \mathrm{~g}$ milk powder from $1000 \mathrm{~g}$ milk). Spray dryed milk powder was produced in $200 \mathrm{dk}$ with $\% 59$ performance $(75 \mathrm{~g}$ milk powder from $1000 \mathrm{~g}$ milk).

In a research spray dryed goat milk powder yield was found as \%86,80 [19]. Another reseracher reported that he produced spray dryed goat milk powder in yield between $\% 82,10$ and $\% 88,48$ [20]. In current study yield of spray drying is lower than literature. The reason of this situation, device may cause product loss.

\subsection{Moisture, $\mathrm{pH}$ and water activity content}

Table 2 indicates the moisture, $\mathrm{pH}$ and water activitiy content of powders produced from freeze dryed and spray dryed milk during storage. As can be seen in Table 2, results of moisture, $\mathrm{pH}$ and water activitiy content were statistically significant $(\mathrm{p}>0.05)$. The highest moisture $(\% 6,29)$ were calculated in spray dryed milk powder in 6.day of storage.

The moisture content of all samples were increased towards the end of storage time. Samples were stored in polyethylene packages. Therefore, they may have got moisture from the air.

In different researches moisture of goat milk powder produced by spray dryer were found as 3,05\% [18]; $4,08 \%$ [21], a reseracher reported moisture content of butter-milk produced by spray dryer as 4\% [22]. Turkish Food Codex (TGK) determined final product moisture content of the milk powder can not be more than 5\% [23]. So in current research only freeze dryed milk powder samples' moisture content are suitable for the literature values.

In current study the highest water activity $(0,49)$ were calculated in spray dryed milk powder in 6.day of storage.Water activity of all samples increased towards the end of storage. Water activity value 
of all spray dryed milk powder was higher than freeze dryed samples. This is an expected result due to increased moisture values of the samples.

Dirim and Talih (2018) reported that cherry laurel powders added whey powders have 4,40\% moisture content and water activity as 0,247 [24]. Reddy et al. (2014) reported that water activity of mixed fruit flavored goat milk powder produced by spray dryer was between $0,16-0,23$ [21].

Water activity values of milk powders for safe storage must be $<0.3$ [25]. So in current study water activity values of freeze dryed and spray dryed milk powder are suitable. Different researcher groups found water activity of goat milk powder produced by spray dryer as 0,309 and 0,27 , respectively [19, 20].

Tontul et al. (2018) found freeze drying provides lower water activity [26]. The reason of this situtation could be the differences in drying mechanisms in both drying techniques. Water removes by sublimation of ice crystals in freeze drying. This situation results a sample with more porous nature. The capillary forces is increased by this porous nature and thereby water activity of the sample decreases [17].

In current study, the highest $\mathrm{pH}(6,86)$ were calculated in freeze dryed milk powder in 2.day of storage. $\mathrm{pH}$ values of all samples increased towards the end of storage. But, $\mathrm{pH}$ values of all freeze dryed milk powder was higher than spray dryed samples. This may be due to differences in production technologies.

A researcher group found $\mathrm{pH}$ value of butter-milk produced by spray dyer between 6,71 and $6,78[27]$.

Table 2. Moisture, $\mathrm{pH}$ and water activitiy content of powder produced from freeze dryed and spray dryed milk during storage time

\begin{tabular}{ccccc}
\hline Product & Storage (day) & \% moisture & $p H$ & Water activity \\
\hline & 2 & $1,78^{\mathrm{a}} \pm 0,83$ & $6,86^{\mathrm{a}} \pm 0,01$ & $0,02^{\mathrm{a}} \pm 0,00$ \\
Freeze dryed milk & 4 & $2,20^{\mathrm{a}} \pm 0,43$ & $6,80^{\mathrm{a}} \pm 0,01$ & $0,02^{\mathrm{a}} \pm 0,01$ \\
powder & 6 & $2,22^{\mathrm{a}} \pm 0,69$ & $6,81^{\mathrm{a}} \pm 0,02$ & $0,08^{\mathrm{a}} \pm 0,07$
\end{tabular}

$\begin{array}{lllll}\text { Spray dyred } & 2 & 5,54^{\mathrm{b}} \pm 2,70 & 6,64^{\mathrm{b}} \pm 0,21 & 0,24^{\mathrm{b}} \pm 0,12 \\ \text { milk powder } & 4 & 5,62^{\mathrm{b}} \pm 1,85 & 6,76^{\mathrm{a}} \pm 0,02 & 0,23^{\mathrm{b}} \pm 0,07 \\ & 6 & 6,29^{\mathrm{b}} \pm 1,32 & 6,79^{\mathrm{a}} \pm 0,01 & 0,49^{\mathrm{b}} \pm 0,00\end{array}$

(4 repetitive data are indicated by letters on the means of comparison with independent $\mathrm{T}$ test. The differentletters indicate that the difference between the two groups is significant., $p<0,05$.)

\subsection{Microbiological analysis}

Table 3 shows the coliform, TAMB (Total Aerofilic Mesophilic Bacteria) and yeast-mould counts of powder produced from freeze dryed and spray dryed milk during storage time. In Table 3, results of coliform, TAMB and yeast-mould counts were statistically significant $(\mathrm{p}>0.05)$. The highest TAMB counts $(4,85 \mathrm{kob} / \mathrm{g})$ were calculated in spray dryed milk powder in 2.day of storage. The highest yeastmould counts $(4,22 \mathrm{kob} / \mathrm{g})$ were calculated in spray dryed milk powder in 4.day of storage. The highest coliform counts $(23,5 \mathrm{kob} / \mathrm{g})$ were calculated in spray dryed milk powder in 2 . and 4 . days of storage. The three microbiological analysis of spray dryed milk powder were higher than freeze dryed samples. Milk powder hits the inner wall of the spray dryer during it is processing and goes out of the device. The results of microbiological analysis are expected to be high as it comes into contact with more areas. But the sample does not come into contact with different areas with the freeze dryer production, so the sterility is higher than spray dryer. Higher sterility indicates that the product may have a longer shelf life. High moisture and water activity values also explain microbial development in spray dryed milk powder. Although the milk used in the study is UHT (commercially sterile), the reason for the high microbial count isdifferences between production technologies.

A researcher group found TAMB count of butter-milk produced by spray dyer between 69,50 $\mathrm{kob} / \mathrm{g}$ and $89 \mathrm{kob} / \mathrm{g}$ [27]. 
Table 3. Coliform, TAMB and yeast-mould counts of powder produced from freeze dryed and spray dryed milk during storage time

\begin{tabular}{ccccc}
\hline Product & Storage (day) & Coliform kob/g & TAMB kob/g & Yeast-mould kob/g \\
\hline & 2 & $0,75^{\mathrm{a}} \pm 0,5$ & $0,62^{\mathrm{a}} \pm 1,24$ & $0,00^{\mathrm{a}} \pm 0,00$ \\
Freeze dryed & 4 & $0,75^{\mathrm{a}} \pm 0,5$ & $0,5^{\mathrm{a}} \pm 1$ & $1,9^{\mathrm{a}} \pm 1,3$ \\
milk powder & 6 & $0,00^{\mathrm{a}} \pm 0,00$ & $0,5^{\mathrm{a}} \pm 1$ & $1,33^{\mathrm{a}} \pm 1,57$ \\
& & & & \\
Spray dyred & 2 & $23,5^{\mathrm{b}} \pm 0,56$ & $4,85^{\mathrm{b}} \pm 0,15$ & $3,95^{\mathrm{a}} \pm 0,51$ \\
milk powder & 4 & $23,5^{\mathrm{b}} \pm 0,56$ & $4,73^{\mathrm{b}} \pm 0,14$ & $4,22^{\mathrm{a}} \pm 0,4$ \\
& 6 & $0,00^{\mathrm{a}} \pm 0,00$ & $4,76^{\mathrm{b}} \pm 0,1$ & $3,36^{\mathrm{b}} \pm 0,42$ \\
\hline
\end{tabular}

(4 repetitive data are indicated by letters on the means of comparison with independent $\mathrm{T}$ test. The different letters indicate that the difference between the two groups is significant., $\mathrm{p}<0,05$.)

\subsection{Colour}

$L^{*}, a^{*}, b^{*}$ values of powder produced from freeze dryed and spray dryed milk during storage time were shown in Table 4. As can be seen in Table 4, all $L^{*}, a^{*}, b^{*}$ values were statistically important (p<0.05). The brightest sample $\left(L^{*}\right)$ was spray dryed milk powder (95.47) in 2. day of storage. The highest $a^{*}$ value $(-3,18)$ was calculated in freeze dryed milk powder in 4 . day of storage. The highest $b^{*}$ value $(12,45)$ was calculated in freeze dryed milk powder in 6 . day of storage.

Freeze dryed samples' $L^{*}$ values were lower; $b^{*}$ and $a^{*}$ values were higher than spray dryed samples. Tontul et al. (2018) reported the decrease in $L^{*}$ values and increase in $b^{*}$ value arise from non-enzymatic browning reactions occurred in samples[26].

Baykal et al. (2018) found $L^{*}, a^{*}, ; b^{*}$ value of goat milk powder produced by spray dryer as 90,$98 ;-1,78 ; 8,67$ respectively [19]. Another researcher group reported that cherry laurel powders added whey powders have $L^{*}$ value as 50,$90 ; a^{*}$ value as 14,$95 ; b^{*}$ value as 10,43 [24].

Table 4. $L^{*}, a^{*}, b^{*}$ values of powder produced from freeze dryed and spray dryed milk during storage time

\begin{tabular}{ccccc}
\hline Product & Storage (day) & $L^{*}$ & $a^{*}$ & $b^{*}$ \\
\hline & 2 & $89,48^{\mathrm{a}} \pm 0,23$ & $-3,05^{\mathrm{a}} \pm 0,06$ & $12,28^{\mathrm{a}} \pm 0,61$ \\
$\begin{array}{c}\text { Freeze dryed milk } \\
\text { powder }\end{array}$ & 4 & $88,9^{\mathrm{a}} \pm 0,31$ & $-3,18^{\mathrm{a}} \pm 0,02$ & $10,56^{\mathrm{a}} \pm 0,66$ \\
& 6 & $90,58^{\mathrm{a}} \pm 0,44$ & $-2,95^{\mathrm{a}} \pm 0,1$ & $12,45^{\mathrm{a}} \pm 0,66$ \\
Spray dyred & 2 & & \\
milk powder & 4 & $95,47^{\mathrm{b}} \pm 0,72$ & $-2,14^{\mathrm{b}} \pm 0,1$ & $7,39^{\mathrm{b}} \pm 1,29$ \\
& 6 & $94,80^{\mathrm{a}} \pm 0,5$ & $-2,24^{\mathrm{b}} \pm 0,11$ & $7,05^{\mathrm{a}} \pm 1,05$ \\
& & $93,67^{\mathrm{a}} \pm 0,92$ & $-2,09^{\mathrm{a}} \pm 0,1$ & $7,83^{\mathrm{a}} \pm 0,24$ \\
\hline
\end{tabular}

(4 repetitive data are indicated by letters on the means of comparison with independent $\mathrm{T}$ test. The different letters indicate that the difference between the two groups is significant., $\mathrm{p}<0,05 . L^{*}$ represent the brightness; $a^{*}$ represent redness/greenness; $b^{*}$ represent yellowness/blueness)

\subsection{Protein content}

The protein content of powder produced from freeze dryed and spray dryed milk in 6.day of storage were shown in Table 5. Protein values were not statistically important ( $p>0.05)$. Figure 1 also indicates protein content on the 6 . day of storage of samples of freze dryed and spray dryed milk powder. However, the results show that protein contents of spray dryed milk powder were lower than freeze dryed samples due to the high moisture contents of the samples produced by spray drying. Last day of storage (6.day) was selected to compare two techniques. It was thought results will be more accurate.

Table 5. Protein content of powder produced from freeze dryed and spray dryed milk in 6.day of storage. 


\section{Freeze dryed milk powder $\quad 27,30^{\mathrm{a}} \pm 0,45$ \\ Spray dryed milk powder $\quad 25,63^{\mathrm{a}} \pm 0,80$}

(4 repetitive data are indicated by letters on the means of comparison with independent $\mathrm{T}$ test. The differentletters indicate that the difference between the two groups is significant., $\mathrm{p}<0,05$.)

Smith (2008) reported protein content of butter-milk produced by spray dryer as \%34 [22]. Another research group found protein content of oil-free whey powder and half fat whey powder produced by spray dryer as $95,1 \mathrm{~g} / \mathrm{kg}$ and $49 \mathrm{~g} / \mathrm{kg}$, respectively [28]. Yetişmeyen and Arı̈̈z (1995) found protein content of butter-milk produced by spray dyer between $\% 32,69$ and $\% 34,73$ [27]. It is reported spray dryed milk powder has $\% 24,40$ protein content [29].

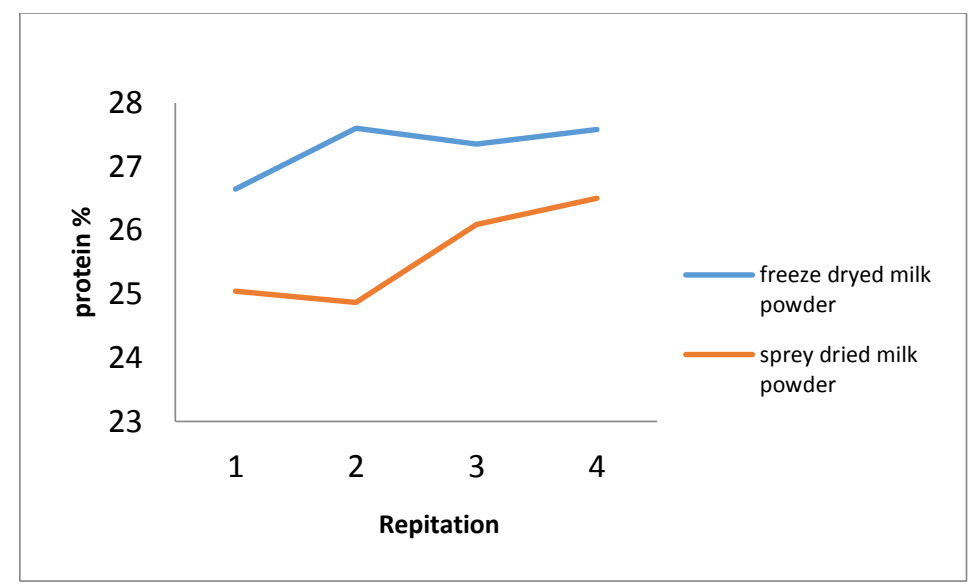

Figure 1. Protein content on the 6. day of storage of samples of freze dryed milk powder and spray dryed milk powder

\subsection{Water absorption and solubility index}

Water absorption and solubility analysis were performed on the day when the samples had the lowest moisture level (2.day) during the storage period. Samples with low moisture were thought to give a clearer result. Increasing moisture content of the samples could change the water absorption and solubility index value.

Figure 2 and Figure 3 indicates water absorption and solubility index of powder produced from freeze dryed and spray dryed milk in 2.day of storage, respectively. Water absorption index of spray dryed milk powder was measured higher than freeze dryed samples. This result shows that it will be easier to swell by taking water for spray dryed powders. Due to the small particle size of the spay dryed samples and the increase of the surface area may be the reason for this situation. Water solubility index of freeze dyed milk powder was measured higher than spray dryed samples. Since the particle size of the freeze dryed samples is larger than spray dryed powders, the dissolution index may be higher.

It is reported that water solubility index was 51,09 for spray-dried jamun juice powder[30]. 


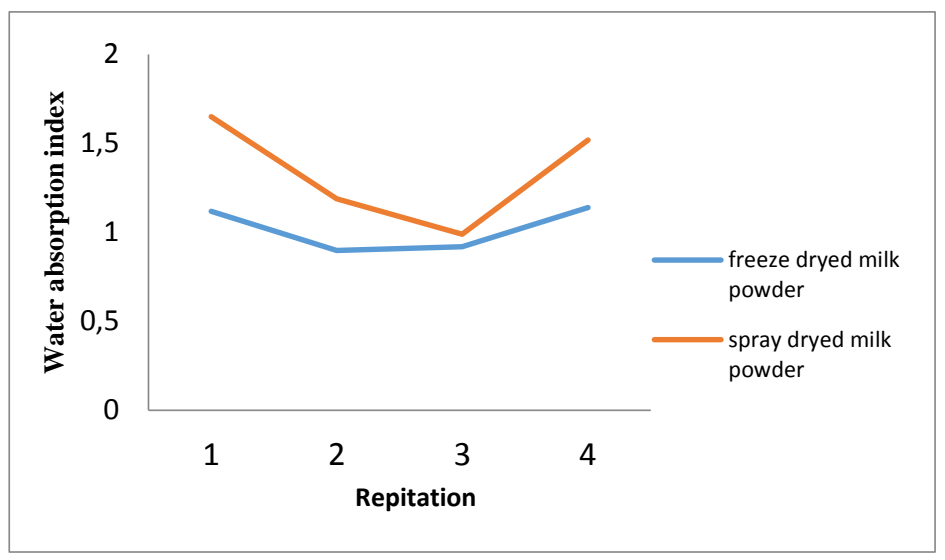

Figure 2. Water absorption index on the 2. day of storage of samples of freze dryed milk powder and spray dryed milk powder

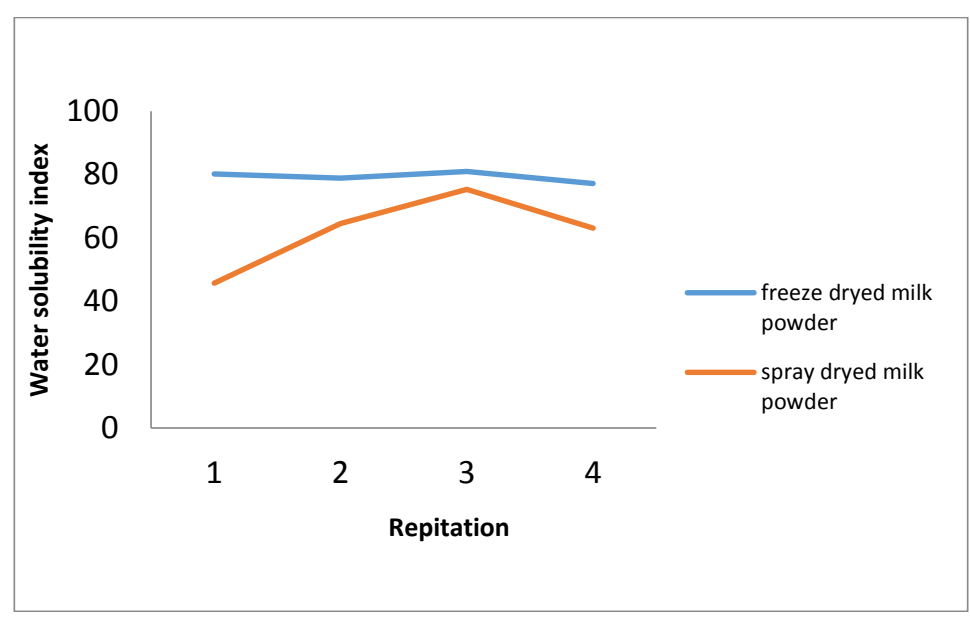

Figure 3. Water solubility index values on the 2. day of storage of samples of freze dryed milk powder and spray dryed milk powder

\subsection{Microscopy}

Images were taken on the day when the samples had the highest moisture level (6.day) during the storage period. Samples with high moisture were thought to give a better image.

Figure 4 (a) and (b) indicates microscopy images of freeze dryed and spray dryed milk powders on the 6. day of storage, respectively. As can be seen in Figure 4 (a) and (b), freeze dryed milk powders have a bright, crystal structure. Particle size is larger than spray dryed samples. Surface features of freeze dryed samples are also the sharpest and prism-shaped. Freeze dryed samples has irregular particles. The samples produced with spray dryer are more powdery, smooth and have spherical shape, have more surface area. There are significant differences between samples.

A group of researcher investigated Scanning Electron Microscopy images of spray dryed mixed of sodium caseinate, maltodextrin, soya oil and water. They found surface of samples are sharp[31].It is reported that freeze dryed coffe samples was observed to be relatively less porous, with flaky structure in Scanning Electron Microscopy [32]. It is found that morphology and size of the spray dryed skim milk are distinctly different from the freeze dryed samples which results in its considerably higher surface area[33]. 


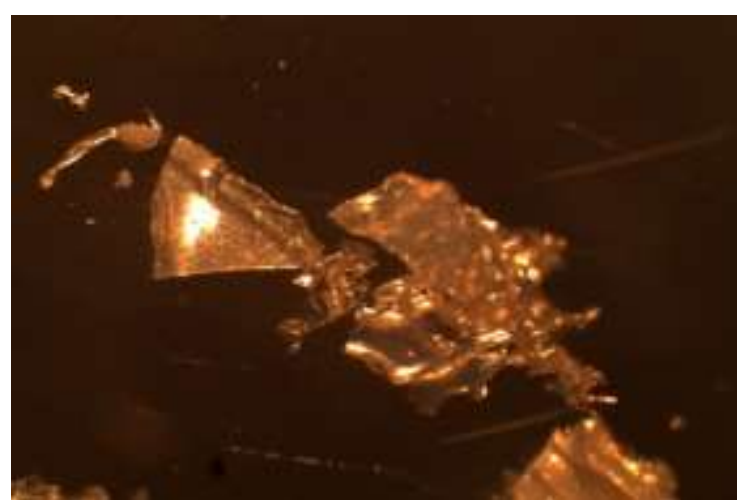

(a)

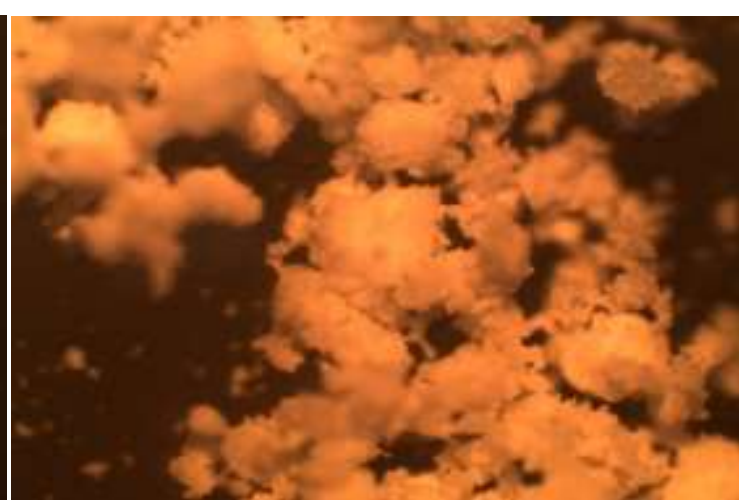

(b)

Figure 4. Microscopy images of freze dryed milk powder (a) and spray dryed milk powder (b) on the 6. day of storage

\section{Conclusion}

Freeze drying and spray drying are two of the technologies used to increase the shelf life of foods. Today, milk powders are produced by spray drying method. In this resarch we investigated the difference between the freeze drying method and spray drying method. Besides this, we investigated if milk powder can be produced with freeze dryer technology as an alternative for spray drying. The two technologies have advantages and disadvantages compared to each other. We found yield of freeze drying is more than spray drying. But the milk powder production time is very long. Moisture and water activity values of milk powder produced by freeze drying were lower. So this can be an advantage for freeze dryed samples. The powders can have long shelf life. Protein content of freeze dryed samples is higher than spray dryed milk powder. Water absorption index of spray drying samples is higher freeze drying samples. This means it is easy to swell for spray dryed powders.

If studies are carried out to reduce drying times of freeze dryer, it can be a supporting technology for the spray dryer in the production of products etc. milk powder, whey...

Although there is alot of research in the literature with spray dryer technique, there is not much study about freeze dryed milk powder. It could not be found many research about milk products powder produced by freeze dryer technique. There are many studies on the comparison of different drying techniques in the literature. However, there has not been a lot of research on the comparison of freeze drying and spray drying techniques. This study is designed to help eliminate the inadequacy in this area.

\section{References}

[1] Mujumdar A.S. 2007. Handbook of Industrial drying. Taylor and Francis group, U.K.

[2] Yıldırım Ç., Güzeler N. 2013. Peyniraltı Suyu ve Yayıkalıının Toz Olarak Değerlendirilmesi. J. Agric. Fac. Ç.Ü., 28 (2): 11-20.

[3] Ratti C. 2001. Hot air and freeze-drying of high-value foods: a review. Journal of Food Engineering, 49: 311-319.

[4] Esper A., Mühlbauer W. 1998. Solar drying- an effective means of food preservation. Renewable Energy. 15: 95-100.

[5] Vega-Mercado H., Gongora-Nieto M. and Barbosa- Canovas G.V. 2001. Advances in dehydration of foods. Journal of Food Engineering, 49: 271-289.

[6] Datta A.K., George J.P. 2002. Development andvalidation of heat and mass transfer models for freeze-drying of vegetable slices. JournalTaylor \& Francis Group, LLC., Floridal of Food Engineering, 52 (1): 89-93.

[7] Ma Y.H., Arsem H. 1982. Low pressure sublimation in combined radiant and microwave freeze drying. In Drying'82, Eds. Mujumdar, A. S., New York: McGraw-Hill.

[8] Filkova I., Huang L.X., Mujumdar A.S. 2006. Industrial Spray Drying Systems, 215-256, Handbook of Industrial Drying, A.S.Mujumdar (Ed.), 3rd Edition, CRCPress, Boca Raton, FL.

[9] Vignolles M.L., Jeantet R., Lopez C. and Schuck P.2007. Free fat, surface fat and dairy powders: Interactions between process and product, Lait, 87:187-236. 
[10] AOAC. 2000. Official Methods of Analysis (18th ed.). Arlington, VA, Association of Official Analytical Chemists.

[11] Halkman A.K. 2005. Gıda Mikrobiyolojisi Uygulamaları. MERCK, Başak Matbaacılık ve Tanıtım Hizmetleri Ltd. Şti., Ankara, $358 \mathrm{~s}$.

[12] Feng N.K.,Zhi J.C., Chun N.L. and Che M.T. 1998. Scavenger and antioxidant properties of prenylflavones isolated from Artocarpus heterophyllus. Free Radical Biology and Medicine, 25: 160-168.

[13] AOAC 2003. Official Methods of Analysis of the Association of Official's Analytical Chemists. 17th ed., Association of Official Analytical Chemists, Arlington, VA, USA.

[14] Hunt M.C., Acton J. C., Benedict R.C., Calkins C.R., Cornforth D.P., Jeremiah L.E., Olson D.P., Salm C.P., Savell J.W., Shivas S.D. 1991. Guidelines for meat colour evaluation. Chicago: American Meat Sci. Assoc. and Nati. Live Stock and Meat Board.

[15] Majors R.E. 2008. Practical aspects of solvent extraction. LCGC N Am; 26 (12): 1158-1166.

[16] Anderson R.A., Conway H.F., Pfeifer V.F. Griffin E.L. 1969. Roll and extrusion-cooking of grain sorghum grits. Cereal Science Today, 14 (11): 372-376.

[17] Troller J.A., Christian J.H.B. 1978. Enzyme reactions and nonenzymatic browning. In: Water Activity and Food, Eds, Academic Press Inc., New York, 48-68.

[18] Ockerman H.W. 1985. Quality control of post-mortem muscle tissue (13th ed.). The Ohio State University. Columbus, OH, USA.

[19] Baykal H., Karais K., Çalışkan Koç G., Dirim S.N. 2018. The properties of cinnamon, carob and ginger enriched goat milk powder enriched goat milk powder. The Journal of Food, 43 (4): 716732.

[20] Namhong T. 2009. Production of instant goat milk powder by spray drying. Department of Food Science and Technology, Rajamangala University of Technology, Lanna, Thailand,181-185.

[21] Reddy R.S., Ramachandraa C.T., Hiregoudar S., Nidoni U., Ramb J., Kammar M. 2014. Influence of processing conditions on functional and reconstitution properties of milk powder made from Osmanabadi goat milk by spray drying. Small Rumin Res, 119: 130-137.

[22] Smith K. 2008. Dried dairy ingredients, Wisconsin Center for Dairy Research, USA.

[23] Anonim 2013. Baharat Tebliği, Türk Gida Kodeksi, Tebliğ No: 2013/12, Resmi Gazete Sayıs1: 28614.

[24] Dirim S.N., Talih M. 2018. The effects of drying agents on properties of freeze dried cherry laurel powders. The Journal of Food. 43 (3): 461-475.

[25] Quek S.Y., Chok N.K., Swedlund P. 2007. The physicochemical properties of spray-dried watermelon powder. Chem Eng Process, 46: 386-392.

[26] Tontul İ., Ergin F., Eroğlu E., Küçükçetin A., Topuz A. 2018. Physical and microbiological properties of yoghurt powder produced by refractance window drying. International Dairy Journal, 85: 169-176.

[27] Yetişmeyen A., Arıöz N. 1995. Determination of the quality characteristic butter milk of powder manufactured by using different concentration rate and drying temperatures. Journal of Food 20 (2): 117-122.

[28] Schuck P., Dolivet A. 2002. Lactose crystallization: determination of $\alpha$ Lactose monohydrate in spray dried dairy products. Lait, 82: 413-421.

[29] Fyfe K., Kravckhuk O., Nguyen A.V., Deeth H., Bhandari B. 2011. Influence of dryer type on surface characteristics of milk powders. Drying Technology, 29: 758-769.

[30] SanthalakshmyS., Bosco S.J.D., Francis S. and Sabeena M. 2015. Effect of inlet temperature on physicochemical properties of spray-dried jamun fruit juice powder. Powder Technology, 274: $37-43$.

[31] Jones J.R., Prime D., Leaper M.C., Richardson D.J., Rielly C.D. and Stapley A.G.F. 2013. Effect of processing variables and bulk composition on the surface composition of spray dried powders of a model food system. Journal of Food Engineering 118, 19-30.

[32] Ishwarya S.P. and Anandharamakrishnan C. 2015. Spray-Freeze-Drying approach for soluble coffee processing and its effect on quality characteristics. Journal of Food Engineering 149 (2015) 171-180. 
[33] Aalaei K., Sjöholm I., Rayner M., Tareke E. 2017. The Impact of different drying techniques and controlled storage on the development of advanced glycation end products in skim milk powders using 1sotope dilution Es1-lc-Ms/Ms. Food Bioprocess Technol., 10: 1704-1714. 